УДК 613.63.001.42: [6:539] - 022.532

\title{
ON THE PROBLEM OF EXPOSURE CONTROL OF NANOMATERIALS AT WORIKPLACE
}

\author{
Demetska O. V., Tkachenko T. Yu.
}

\section{SI «Institute for Occupational Health of National Academy of Medical Sciences of Ukraine», Kyiv}

Background. In the present situation, when production and use of nanomaterials are developing very quickly, assessment of risks in the field of nanotechnologies, hygienic regulation, exposure control of nanomaterials at workplace, becomes a tasks of high priority. All these need an assessment of workers' exposure to nanoparticles in occupational settings.

Purpose. To determine nanoparticle emissions to the air of the working zone in different work activities and to evaluate modern methods of the exposure control of nanomaterials at workplace.

Materials and methods. A concentration of nanoparticles in the air of the working zone was measured by the diffusion aerosol spectrometer DAS-2702.

Results. According to levels of nanoparticle emissions to the air of the working zone, the E-beam synthesis in vacuum as well as traditional industrial processes (electric welding, secondary lead melting) are the most potentially dangerous.

Conclusions. Nanoparticle emissions to the air of the working zone can occur in both nanotechnological and traditional processes. An exposure control is needed in both situations and requires modern measuring devices and specially developed sampling methods.

Key words: nanoparticles, nanomaterials, air of the working zone

\section{Introduction}

Nowadays, high-priority issues in nanosafety are as followed: investigations of the toxicity of nanoparticles and new material; monitoring of occupational exposure; analysis of the potential risks for human health and the environment as well as occupational hazards; minimizing negative effects and sharing the information on probable risks. Today, a nanomaterial is defined as material with at least one outer dimension in the scale of $1-100 \mathrm{~nm}$ or with inner or surface nanosized structure. A nanostructural material is described as the material, which is characterized by inner or surface nanostructure. Nanomaterials are devided into nanoobjects (nanoparticles, nanofibres, nanoplates, etc.) and nanostructural materials (nanostructural powder, nanocomposite, etc.). A nanoparticle is a nanoobject with all three dimensions in the nanoscale [1,2].

At the current stage of nanotechnology development, when the number of workers, having occupational contact with nanomaterials, is constantly increasing, the assessment of risks in the sphere of nanotechnologies, hygienic regulations, and exposure control of nanomaterials at workplace, turn to be tasks of high priority. The nanomaterial control is aimed at detection, identification and characterization of nanomaterials in the air of the working zone. All this is impossible without assessment of exposure at workplace.
The British Standards Institution (BSI) recommends the following devices for direct measuring of the number, mass and surface area for nanopartcles [3]:

Measurement of the number of nanoparticles:

1) Condensation particle counter (CPC) provides real-time number concentration measurements between particle diameter detection limits. They operate by condensing vapor onto sampled particles and detecting/counting the droplets formed;

2) Differential mobility particle sizer (DMPS) is used for real-time size-selective detection of the number of concentrations and shows a number-based size distribution;

3) Electron microscopy (scanning electronic microscopy (SEM), transparent electron microscopy TEM) can provide information on size-specific aerosol number concentrations.

\section{Measurements of mass of nanoparticles:}

1) Size selective static sampler (with a cut-off point of approximately $100 \mathrm{~nm}$ ) is used for analyzing samples by gravimetric weighing or for chemical analyses. Some cascade impactors are with selection points around $100 \mathrm{~nm}$ and can be used for such purposes;

2) Tapered element oscillating microbalance (TEOM) is a sensitive real-time monitor, which can be used to measure nanoaerosol mass concentrations online, with a suitable size-selective inlet. 


\section{Surface area measurements:}

1) Diffusion charger is used for a real-time measurement of aerosol active surface area. Diffusion chargers are specific only for nanoparticles if used with an appropriate inlet pre-separator;

2) Electrostatic low pressure impactor (ELPI) makes it possible to provide a real-time size-selective (aerodynamic diameter) detection of an active surface area concentration;

3) Electron microscopy (SEM, TEM) can show information on a particle surface area concerning the size. Using TEM it is possible to receive the direct information on the projected area of the collected particles, related to a geometric area for some particle shapes.

The abovementioned devices can be also used for indirect measurements [3]. The ELPI data on the aerosol size distributions can be interpreted in terms of the number or mass concentration; size-selected samples can be further analyzed off-line. The same way, with DMPS it is possible to calculate mass concentrations of aerosols on the base of aerosol size distribution. ELPI and DMPS can be used for mass concentration of aerosols calculations only if the particle charge and density are assumed or known. DMPS, giving aerosol size distribution, also makes it possible to calculate a surface area. ELPI and DMPS can be used in parallel: differences in the measured aerodynamics and mobility help to obtain particle fractal dimension, which can be used to estimate a surface area.

The purpose of the present work was to determine emission of nanoparticles to the air of the working zone under different working processes and to evaluate modern methods of the exposure control of nanomaterials in the workplace environment.

\section{Materials and methods}

The concentration of nanoparticles in the air of the working zone was measured by the diffusion aerosol spectrometer DAS-2702 (a diffusion aerosol charger).

Researches on the following production processes were carried out: the E-beam synthesis in vacuum of metal powders with nanostructure; mechanical activation and mechanical synthesis of nanosized powders of metals; chemical synthesis of CdS nanoparticles in gelatin with and without heating; melting of secondary lead (an experimental model); electric welding; processing of the plant raw materials; manual dosing of the chrysotile asbestos.

\section{Results and discussion}

The first step in organization of the control of a hazard is to prepare a list of compounds, which can enter the air of the working zone at every workplace. In this, it is necessary to take into account special features of technological processes, temperature regime, number of emitted hazard compounds as well as physicalchemical properties of substances, being under the control, and their ability to transformation due to oxidation, degradation, hydrolysis or other process. Also, duration of workers' presence in the production area within a shift as well as a type of a workplace (permanent or temporary) should be taken into account.

Elements of the system of the exposure control in the workplace environment include: monitoring of hazardous work conditions; control of ventilation system effectiveness; control of personal protective equipment (with account of its changes and/or cleaning frequency; storage conditions); control of the equipment sanitization; control of keeping to instructions on safety.

Until a nanomaterial class of hazard has not been established officially (in the frame of hygienic regulations), each individual nanomaterial should be considered as a new product, which can be potentially hazardous for humans. In order to find a dangerous technological area, processes and sources of nanoaerosol emissions to the air of the working zone, control of its maximum concentration, is carried out.

Our own experimental researches show that nanoparticle emissions to the air of the working zone can occur during processes, where nanomaterials are being involved, as well as under traditional processes, which are not related to nanomaterial processing or production (Table) [4, 5].

The data on nanoparticle concentrations can be compared preliminary with the following benchmark levels:

- for metals, metal oxides and other biologically stable dispersed nanomaterials with density $>6000 \mathrm{~kg} / \mathrm{m}^{3}$ concentration of nanoparticles in the range of $1-100 \mathrm{~nm}$ should not exceed 20000 particles $/ \mathrm{cm}^{3}$;

- for biologically stable dispersed nanomaterials with the density of $<6000 \mathrm{~kg} / \mathrm{m}^{3}$ concentration of nanoparticles, ranging $1-100 \mathrm{~nm}$, should not exceed 40000 particles $/ \mathrm{cm}^{3}$. 
Levels of nanoparticle emissions under various work activity

\begin{tabular}{|l|l|c|c|}
\hline No & \multicolumn{1}{|c|}{ Work activity } & \multicolumn{1}{|c|}{$\begin{array}{c}\text { Background level, } \\
\text { particles/cm } \mathbf{c}^{\mathbf{1}}\end{array}$} & $\begin{array}{c}\text { Concentration of nanoparticles } \\
\text { in work processes, particles/cm }\end{array}$ \\
\hline 1 & $\begin{array}{l}\text { E-beam synthesis in vacuum of the metal powders } \\
\text { with nanostructure }\end{array}$ & 14666 & 135618 \\
\hline 2 & $\begin{array}{l}\text { Mechanical activation and mechanical synthesis } \\
\text { of nanosized powders of metals }\end{array}$ & 8738 & $10446-13530$ \\
\hline 3 & $\begin{array}{l}\text { Chemical synthesis of CdS nanoparticles in gelatin } \\
\text { (without heating) }\end{array}$ & 14000 & $21000-29000$ \\
\hline 4 & $\begin{array}{l}\text { Chemical synthesis of CdS nanoparticles in gelatin } \\
\text { with heating }\end{array}$ & 14000 & $28000-42000$ \\
\hline 5 & Melting of the secondary lead (experimental model) & 8535 & $26000-50000$ \\
\hline 6 & Electric welding & 30000 & $80000-120000$ \\
\hline 7 & Processing of the plant raw materials & 5000 & $5000-10000$ \\
\hline 8 & Manual dosing of the chrysotile asbestos & 12000 & $20000-25000$ \\
\hline
\end{tabular}

According to these benchmark levels the E-beam, synthesis in vacuum as well as in traditional work processes (electric welding, secondary lead melting), are most potentially dangerous.

At the same time the assessment of the nanomaterial exposure at workplace requires not only determination of nanoparticle concentrations in the air of the working zone, but, also, use of different sampling methods for further physical-chemical analysis of nanoparticles.

For example, in order to measure physical properties of nanoparticles, a method of their sampling, described in [6], can be used. The method includes mixing an aerosol sample with vapor absorber in the camera-receiver with further vapor condensing onto sampled particles. After this, physical measurements can be done, using registration by Tyndall scattering (light scattering of particles).

For determination of size, elemental composition and mass concentration of nanoparticles in the air of the working zone the next method can be used. The air is aspirated by the sampler through Zaitsev absorber, which contains deionized water. The sample is filtered, using syringe with a membrane disk filter (filter diameter $25 \mathrm{~mm}$, pore size $100 \mathrm{~nm}$ ) in the attached filter holder. The filtration makes it possible to collect only particles with size $<100 \mathrm{~nm}$. The concentration and elemental composition of nanoparti-

\section{Literature}

1. ISO/TS 80004:2015. Nanotechnologies - Vocabulary, Part 2: Nano-objects, $10 \mathrm{p}$.

2. ISO/TS 80004:1:2015. Nanotechnologies - Vocabulary, Part 1: Core terms, 3 p. cles are determined by ICP-AEC method, and their size can be established with a nanosizer [7].

In order to increase the accuracy of qualitative and quantitative determination of metal nanoparticles in the gas media, a sampling process can include stretching of the gas phase through the filter (on the base of propylene microfibers), which detains particles of $>100 \mathrm{~nm}$, with further concentration of nanoparticles in the absorber solution ( $0,05 \%$ water solution of mildly cationic flocculant), for preventing their aggregation [8].

An approach to hygienic monitoring of nanoparticle content in the air of the working premises is based on the use of water-soluble polyvinylpyrolidone nanofilters, able to detain aerosol particles, sized $1-10 \mu \mathrm{m}$ [9].

\section{Conclusion}

Nanoparticle emissions to the air of the working zone can occur during work activities, related to nanoparticle processing and/or production (e. g. E-beam synthesis in vacuum of metal nanostructure powders) as well as under traditional work processes not related to nanotechnologies (e. g. electric welding). An exposure control is needed in both situations and requires modern measuring devices and specially developed sampling methods.

3. BSI-British Standards. 2007, Nanotechnologies. Guide to safe handling and disposal of manufactured nanomaterials. Part 2, PD 6699-2, BSI.

4. Demetska, O. V., Andrusishina, I. M., Tkachenko, T. Yu. 2013, "A comparative characteristics of risk levels for 
persons, who contact professionally with technogeneous nanoparticles", Ukrainian Journal of Occupational Health, no. 4, pp. 47-53 (in Ukrainian).

5. Demetska, O. V., Leonenko, O. B., Tkachenko, T. Yu., Suprun, V. I. 2012, "Study on the dynamics of concentration of ultrafine particles, emitted during welding", Ukrainian Journal of Occupational Health, no. 1, pp. 3-7 (in Ukrainian).

6. Kundiev, Yu. I. [et. al.]. 2012, Method for determination of nanoparticles in air, Patent for Utility Model № 69801 .
7. Movchan, V. O. [et al.]. 2012, Method for determine of nanoparticles in working zone air, Patent for Utility Model № 72951.

8. Babii, F. F. [et al.] 2013, Method of gas medium sampling for determination of presence and concentration of nano-particles of metals, Patent for Utility Model № 77782 .

9. Yavorovskyi, O. P. [et al.]. 2012, Method for hygienic control of content of nano-particles in the air of working area, Patent for Utility Model № 75831.

\section{Аемеиыка О. В., Ткаченко Т. Ю.}

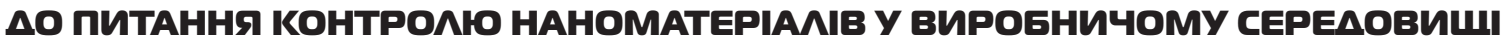

\section{$\Delta У$ «Інститут меАишини праші НАМН України», М. Київ}

Стан проблеми. В сучасних умовах, коли швидкими темпами зростає виробництво та застосування наноматеріалів, першочерговим завданням є оцінка ризику в сфері нанотехнологій, гігієнічне нормування, контроль за наноматеріалами у виробничому середовищі. Це, в свою чергу, потребує оцінки експозиції працюючих на робочих місцях. Мета дослідження - визначити емісію наночастинок у повітря робочої зони під час різних виробничих процесів та оцінити сучасні методи контролю за наноматеріалами у виробничому середовищі.

Матеріали та методи дослідження. Концентрацію наночастинок у повітрі робочої зони вимірювали на дифузному аерозольному спектрометрі ДАС-2707.

Результати. Відповідно до рівнів емісії наночастинок у повітря робочої зони найбільша потенційна небезпека пов'язана з таким нанотехнологічним процесом, як електронно-променевий синтез у вакуумі, а також із виробничими процесами, які не пов'язані з нанотехнологіями (електрозварювання, виплавка вторинного свинцю).

Висновки. Встановлено, що емісією наночастинок у повітря робочої зони можуть супроводжуватися як виробничі процеси, кінцевим продуктом яких є наноматеріали, так і традиційні процеси, що не є нанотехнологічними. Виробничий контроль наноматеріалів потребує сучасних вимірювальних пристроїв та застосування спеціально розроблених для даних цілей методик відбору проб.

Ключові слова: наночастинки, наноматеріали, повітря робочої зони

\section{Аемешкая А. В., Ткаченко Т. Ю.}

\section{К BOПPOCУ КОНТРОАЯ НАНОМАТЕРИАПОВ В ПРОИВВОАСТВЕННОЙ СРЕАЕ}

\section{ГУ «Институт медицины труда НАМН Украины», г. Киев}

Состояние проблемы. В современных условиях, когда быстрыми темпами растет производство и применение наноматериалов, первоочередной задачей является оценка риска в сфере нанотехнологий, гигиеническое нормирование, контроль наноматериалов в производственной среде. Это в свою очередь требует оценки экспозиции работающих на рабочих местах.

Цель исследования - определить эмиссию наночастиц в воздух рабочей зоны при различных производственных процессах и оценить современные методы контроля наноматериалов в производственной среде.

Материалы и методы исследования. Концентрацию наночастиц в воздухе рабочей зоны измеряли на диффузном аэрозольном спектрометре ДАС-2707.

Результаты. Исходя из уровней эмиссии наночастиц в воздух рабочей зоны, наиболее потенциальная опасность связана с таким нанотехнологическим процессом, как электронно-лучевой синтез в вакууме, а также с производственными процессами, которые не связаны с нанотехнологиями (электросварка, выплавка вторичного свинца).

Bыводы. Установлено, что эмиссией наночастиц в воздух рабочей зоны могут сопровождаться как производственные процессы, конечным продуктом которых являются наноматериалы, так и традиционные процессы, которые не являются нанотехнологическими. Производственный контроль наноматериалов требует современных измерительных устройств и применения специально разработанных для этих целей методик отбора проб.

Ключевые слова: наночастицы, наноматериалы, воздух рабочей зоны

Надійшла: 7 жовтня 2015 р.

Контакта особа: Демецька О. В., кандидат біологічних наук, ДУ «Інститут медицини праці НАМН України», буд. 75, вул. Саксаганського, м. Київ, 01033. Тел.: + 3804428943 66. Електронна пошта: dalexandra@ukr.net 